\title{
REGULACJA PRAWNA WPROWADZANIA DO OBROTU PRODUKTÓW BIOBÓJCZYCH W ŚWIETLE ROZPORZĄDZENIA PARLAMENTU EUROPEJSKIEGO I RADY NR 528/2012 - WYBRANE ZAGADNIENIA
}

\section{LEGAL REGULATION ON MARKETING BIOCIDAL PRODUCTS IN THE LIGHT OF THE REGULATION NO. 528/2012 OF THE EUROPEAN PARLIAMENT AND OF THE COUNCIL - SELECTED ISSUES}

\section{STRESZCZENIE}

Prawna regulacja wprowadzania do obrotu produktów biobójczych odznacza się obecnie współistnieniem krajowych niezharmoniszawie.

"Doktor nauk prawnych, Wydział Prawa i Administracji UKSW w War- 
zowanych aktów prawnych obok bezpośrednio skutecznych przepisów unijnych, takich jak rozporządzenie Parlamentu Europejskiego i Rady nr 528/2012 z dnia 22 maja 2012 r. w sprawie udostępniania na rynku i stosowania produktów biobójczych, które z dniem 1 września 2013 r. zastąpiło dotychczasową dyrektywę 98/8/WE. Powyższa niejednolitość częściowo wynika z trwającego programu przeglądu substancji czynnych produktów biobójczych, którego zakończenie (planowane na 31 grudnia 2024 r.) ma doprowadzić do urzeczywistnienia spójnego systemu reglamentacji produktów biobójczych w ramach UE.

W opracowaniu przedstawiono najważniejsze modyfikacje stanu prawnego wynikające z ustanowienia rozporządzenia nr 528/2012. Odniesiono się pokrótce do zakresu przedmiotowego tego aktu i jego podstawowych założeń, legalnej definicji produktów biobójczych oraz ich klasyfikacji, wskazano na tryby udzielania i zmiany pozwoleń na produkty biobójcze, a także na zagadnienie ochrony danych o substancjach czynnych i produktach biobójczych.

W podsumowaniu dokonano syntetycznej oceny rozporządzenia, podkreślając jego rolę w ustanawianiu zintegrowanych procedur administracyjnych w sprawach indywidualnych pozwoleń na produkty biobójcze, wydawanych zarówno przez organy krajowe, jak i Komisję Europejską.

\section{Słowa kluczowe}

Produkty biobójcze; rozporządzenie nr 528/2012; rozporządzenie biocydowe; pozwolenie.

\section{ABSTRACT}

The legal regulation of the placing of biocidal products on the market is currently characterized by coexistence of national non-harmonized legal acts and directly effective EU legislation, such as the Regulation No. 528/2012 of the European Parliament and of the Council dated 22 May 2012 concerning the making available on the market and use of biocidal products, that as of 1 September 2013 superseded the previous directive 98/8/EC. The above inconsistency stems partially from the ongoing biocide active substance review program, the conclusion of which (planned on 31 December 2024) is to lead to realization of a coherent system of rationing of biocides within the EU.

The study contains the most important modifications of the 4/2014 legal status resulting from the establishment of the Regulation 
No. 528/2012. It briefly referred to the material scope of the act and its basic assumptions, the legal definition of biocidal products and the classification thereof, and it indicated the modes of granting and changing the authorisations for biocides, as well as the issue of active substances and biocides data protection.

In the summary, a synthetic assessment of the act was made, emphasizing its role in establishing integrated administrative procedures in the cases of individual authorisations for biocides, issued by both national bodies and the European Commission.

\section{Keywords}

Biocidal products; regulation No. 528/2012; Biocidal Products Reglamentation; authorisation.

\section{WPROWADZENIE}

Produkty biobójcze (biocydy) należą do kategorii produktów, których warunki wprowadzania do obrotu są regulowane w prawie Unii Europejskiej. Uprzednio obowiązującą dyrektywę Parlamentu Europejskiego i Rady nr 98/8/WE (BPD) ${ }^{1}$ zastąpiono 1 września 2013 r. rozporządzeniem nr 528/12 w sprawie udostępniania na rynku i stosowania produktów biobójczych $(\mathrm{BPR})^{2}$, co sprawia, że w tej materii ostatecznie przyjęto model harmonizacji poprzez normy bezpośrednio skuteczne w krajowych porządkach prawnych. Ze względu na trwający okres przeglądu substancji czynnych produktów biobójczych (który ma zakończyć się do 31 grudnia 2024 r. $^{3}$ ), wydawanie pozwo-

1 Dyrektywa Parlamentu Europejskiego i Rady 98/8/WE z dnia 16 lutego 1998 r. dotycząca wprowadzania do obrotu produktów biobójczych (BPD Biocidal Products Directive), Dz.Urz. UE L 123 z 24.04.1998, s. 1 ze zm.

2 Rozporządzenie Parlamentu Europejskiego i Rady nr 528/2012 z dnia 22 maja 2012 r. w sprawie udostępniania na rynku i stosowania produktów biobójczych (BPR - Biocidal Products Reglamentation), Dz.Urz. UE L 167 z 27.06.2012, s. 1, ze zm.

3 Por. art. 89 ust. 1 BPR w brzmieniu przyjętym przez art. 1 rozporządzenia Komisji (UE) nr 736/2013 z dnia 17 maja 2013 r. zmieniającego rozporządzenie Parlamentu Europejskiego i Rady (UE) nr 528/2012 w odniesieniu do 
leń dopuszczających biocydy do obrotu może jednak następować $\mathrm{w}$ ramach różnych procedur, zarówno unormowanych w BPR, jak i zgodnie z autonomicznymi regulacjami krajowy$\mathrm{mi}^{4}$. Ta różnorodność (choć nie dowolność) trybów postępowania pogłębiana jest dodatkowo szczegółowością legislacji. Przejrzystości terminologicznej i proceduralnej nie sprzyja również niedostosowanie do BPR w koniecznym zakresie przepisów dotychczasowej ustawy z dnia 13 września 2002 r. o produktach biobójczych $^{5}$ i opieszałość prac nad nową regulacją ustawową ${ }^{6}$. W związku z powyższym, za zasadne uznano przedstawienie najważniejszych modyfikacji stanu prawnego wynikających z wejścia w życie rozporządzenia biocydowego.

\section{ZAKRES STOSOWANIA ROZPORZĄDZENIA NR 528/2012 I JEGO PODSTAWOWE ZAŁOŻENIA}

Zgodnie $\mathrm{z}$ art. 1 BPR celem tego aktu jest poprawa funkcjonowania rynku wewnętrznego poprzez harmonizację przepisów dotyczących udostępniania na rynku i stosowania produktów biobójczych, przy jednoczesnym zapewnieniu wysokiego poziomu ochrony zdrowia ludzi i zwierząt oraz środowiska. Zbliżanie krajowych porządków prawnych za pośrednictwem dyrektywy 98/8/WE uznano bowiem za niewystarczające, wiele zaś z ustanowionych w jej ramach instytucji nie uzyskało większego znaczenia. Dodatkowym problemem okazały się opóźnienia w programie przeglądu substancji czynnych biocydów, spowodowane złożonością dokonywanej oceny, niewystarczającymi zasobami ludzkimi, brakiem doświadczenia w sporządzaniu dokumen-

czasu trwania programu prac polegających na ocenie istniejących biobójczych substancji czynnych, Dz.Urz. UE L 204 z 31.07.2013, s. 25.

4 Zastosowanie tzw. procedury narodowej lub wg norm europejskich zależy od statusu substancji czynnej zawartej w produkcie (jej zatwierdzenia) w ramach unijnego programu przeglądu.

5 Tekst jedn.: Dz.U. z 2007 r. Nr 39, poz. 252 ze zm., dalej jako: u.p.b.

6 Por. projekt nowej ustawy o produktach biobójczych dostępny na stronie Ministerstwa Zdrowia: http://www.mz.gov.pl (data dostępu: 5.09.2014 r.). 
tacji przez podmioty zgłaszające substancje do przeglądu, koniecznością opracowania odpowiedniej metodologii badawczej oraz liczebnością substancji podlegających ocenie ${ }^{7}$.

Projekt przedmiotowego rozporządzenia został zgłoszony przez Komisję Europejską w czerwcu 2009 r., przyjęty z pewnymi poprawkami przez Parlament Europejski i Radę, a następnie podpisany 22 maja 2012 r. Rozporządzenie formalnie weszło w życie dwudziestego dnia po jego publikacji w Dzienniku Urzędowym UE, tj. 17 lipca 2012 r., jednak jego przepisy generalnie stosuje się (zgodnie z art. 97 BPR), począwszy od 1 września 2013 r. Mimo krótkiego okresu obowiązywania, treść BPR podlegała już modyfikacjom ${ }^{8}$, dla jego stosowania wydano także szereg aktów wykonawczych ${ }^{9}$.

7 Por. sprawozdanie Komisji Europejskiej dla Rady i Parlamentu Europejskiego z dnia 8 października 2008 r. w sprawie stosowania dyrektywy 98/8/WE: Report from the Commission to the Council and the European Parliament - Evaluation of the implementation of Directive 98/8/EC concerning the placing of biocidal products on the market (submitted in accordance with Article 18(5) of the Directive) and progress report on the work programme referred to in Article 16(2) of the same Directive, $\operatorname{COM(2008)~} 620$ final (tekst dostępny w bazie PreLex na stronie internetowej: http://ec.europa.eu, data dostępu: 5.09.2014 r.), s. 6.

8 Por. rozporządzenie Parlamentu Europejskiego i Rady (UE) nr 334/2014 z dnia 11 marca 2014 r. zmieniające rozporządzenie (UE) nr 528/2012 w sprawie udostępniania na rynku i stosowania produktów biobójczych w odniesieniu do niektórych warunków dostępu do rynku, Dz.Urz. UE L 103 z 5.04.2014, s. 22; rozporządzenie delegowane Komisji (UE) nr 837/2013 z dnia 25 czerwca 2013 r. zmieniające załącznik III do rozporządzenia Parlamentu Europejskiego i Rady (UE) nr 528/2012 w odniesieniu do wymogów informacyjnych dotyczących pozwoleń na produkty biobójcze, Dz.Urz. UE L 234 z 3.09.2013, s. 1; rozporządzenie delegowane Komisji (UE) nr 736/2013 z dnia 17 maja 2013 r. zmieniające rozporządzenie Parlamentu Europejskiego i Rady (UE) nr 528/2012 w odniesieniu do czasu trwania programu prac polegających na ocenie istniejących biobójczych substancji czynnych, Dz.Urz. UE L 204 z 31.07.2013, s. 25.

9 Por. m.in. rozporządzenie Komisji (UE) nr 354/2013 z dnia 18 kwietnia 2013 r. w sprawie zmian produktów biobójczych, na które udzielono pozwolenia zgodnie z rozporządzeniem Parlamentu Europejskiego i Rady (UE) nr 528/2012, Dz.Urz. UE L 109 z 19.04.2013, s. 4; rozporządzenie wykonawcze Komisji (UE) nr 564/2013 z dnia 18 czerwca 2013 r. w sprawie opłat i należności wnoszonych na rzecz Europejskiej Agencji Chemikaliów na podstawie rozporządzenia Parlamentu Europejskiego i Rady (UE) nr 528/2012 w spra- 
Zakresem rozporządzenia $\mathrm{nr} 528 / 2012$ zgodnie z art. 1 ust. 2 objęto m.in. zasady:

„a) sporządzenia, na poziomie Unii, wykazu substancji czynnych, które mogą być wykorzystywane w produktach biobójczych;

b) wydawania pozwoleń na produkty biobójcze;

c) wzajemnego uznawania pozwoleń w Unii;

d) udostępniania na rynku i stosowania produktów biobójczych w jednym lub kilku państwach członkowskich lub w Unii;

e) wprowadzania do obrotu wyrobów poddanych działaniu produktów biobójczych".

Spod stosowania BPR wyłączono natomiast produkty, które spełniają wymogi definicyjne nie tylko biocydu, ale również innej kategorii produktowej (tzw. borderlines products - produkty z pogranicza), chyba że produkt taki jest przeznaczony do zastosowań nie objętych przepisami dotyczącymi innej kategorii produktów (art. 2 ust. 2 BPR).

W porównaniu z dyrektywą 98/8/WE, w rozporządzeniu nr 528/2012 wprowadzono szereg nowych rozwiązań prawnych, polegających przede wszystkim na:

- rozszerzeniu zakresu przedmiotowego aktu poprzez objęcie definicją produktów biobójczych wyrobów poddanych działaniu produktu biobójczego w dotychczasowym rozumieniu oraz produktów wytwarzanych in situ ${ }^{10}$;

wie udostępniania na rynku i stosowania produktów biobójczych, Dz.Urz. UE L 167 z 19.06.2013, s. 17; rozporządzenie delegowane Komisji (UE) nr 492/2014 z dnia 7 marca 2014 r. uzupełniające rozporządzenie Parlamentu Europejskiego i Rady (UE) nr 528/2012 w odniesieniu do zasad odnawiania pozwoleń na produkty biobójcze w procedurze wzajemnego uznawania, Dz.Urz. UE L 139 z 14.05.2014, s. 1; rozporządzenie wykonawcze Komisji (UE) $\mathrm{nr}$ 414/2013 z dnia 6 maja 2013 r. określające procedurę wydawania pozwoleń dla takich samych produktów biobójczych zgodnie z rozporządzeniem Parlamentu Europejskiego i Rady (UE) nr 528/2012, Dz.Urz. UE L 125 z 7.05.2013, s. 4.

10 Por. art. 3 ust. 1 pkt a) BPR. 
- wprowadzeniu harmonogramu obowiązkowego oznaczania wyrobów poddanych działaniu produktów biobójczych ${ }^{11}$;

- uregulowaniu (obok pozwoleń organów krajowych) unijnych pozwoleń na wprowadzanie do obrotu niektórych produktów, wydawanych przez Komisję Europejską przy współudziale Europejskiej Agencji Chemikaliów $(\mathrm{ECHA})^{12}$;

- doprecyzowaniu kwestii związanych z zatwierdzaniem substancji czynnych produktów biobójczych (w tym nowych substancji) ${ }^{13}$;

- zniesieniu dotychczasowych procedur włączania substancji niskiego ryzyka i substancji bazowych do załącznika I A i I B dyrektywy 98/8/WE;

- wprowadzeniu uproszczonej procedury dotyczącej rodzin produktów biobójczych ${ }^{14}$; rejestracji takich samych produktów ${ }^{15}$, jak również umożliwieniu uchylenia przez organ rejestrujący wymogu dostarczenia danych, które nie są konieczne lub są niemożliwe do przedłożenia w konkretnym przypadku' ${ }^{16}$;

- uproszczeniu postępowań w sprawie zmiany treści pozwoleń ${ }^{17}$;

- usprawnieniu procedur (sekwencyjnego bądź równoległego) wzajemnego uznawania pozwoleń ${ }^{18}$;

- wprowadzeniu mechanizmu udzielania pozwoleń na handel równoległy ${ }^{19}$;

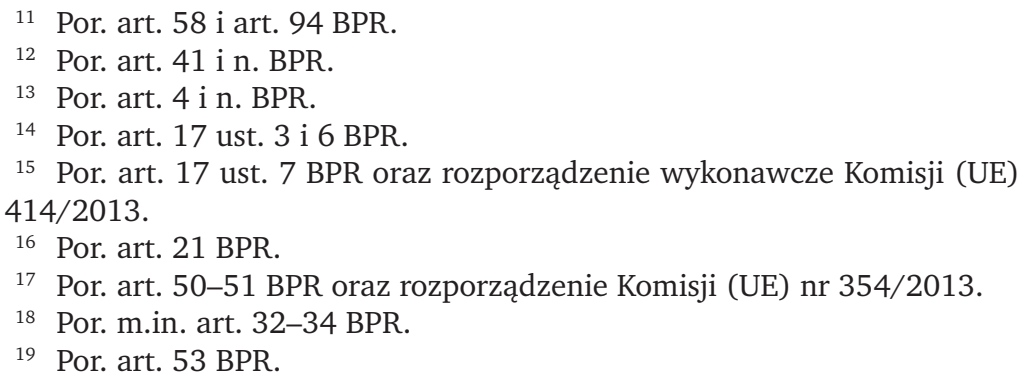


- uregulowaniu zasad służących redukcji przeprowadzanych testów na zwierzętach ${ }^{20}$;

- uproszczeniu zasad ochrony danych przedkładanych przez przedsiębiorców ${ }^{21}$;

- harmonizacji i koordynacji opłat administracyjnych ${ }^{22}$.

Powyższe rozwiązania korygują system prawnej reglamentacji udostępniania biocydów na unijnym rynku, nie oznaczają jednak zmiany kierunku unijnej polityki w tym obszarze. Poniżej omówiono pokrótce wybrane zagadnienia związane z kwalifikacją produktów oraz wymogami i gwarancjami proceduralnymi odnoszącymi się do trybów udzielania pozwoleń dopuszczających biocydy do obrotu.

\section{POJĘCIE PRODUKTÓW BIOBÓJCZYCH I ICH RODZAJE}

W dotychczasowym stanie prawnym podstawę kwalifikacji jako produktu biobójczego stanowił (implementujący dyrektywę 98/8/WE) art. 3 pkt 1 u.p.b. Wiążącą definicję zawiera obecnie art. 3 ust. 1 lit. a) BPR, zgodnie z którym pojęcie produkt biobójczy oznacza:

- „każdą substancję lub mieszaninę w postaci, w jakiej jest dostarczana użytkownikowi, składającą się z jednej lub kilku substancji czynnych lub zawierającą lub wytwarzającą jedną lub więcej substancji czynnych, której przeznaczeniem jest niszczenie, odstraszanie, unieszkodliwianie organizmów szkodliwych, zapobieganie ich działaniu lub zwalczanie ich w jakikolwiek sposób inny niż działanie czysto fizyczne lub mechaniczne;

- każdą substancję lub mieszaninę, wytwarzaną z substancji lub mieszanin, które same nie są objęte zakresem tiret pierwszego, przeznaczoną do niszczenia, odstraszania, unieszkodliwiania organizmów szkodliwych,

20 Por. art. 62 BPR.

21 Por. art. 59 i n. oraz art. 95 BPR.

22 Por. art. 80 BPR oraz rozporządzenie Komisji (UE) nr 564/2013. 
zapobiegania ich działaniu lub zwalczaniu ich w jakikolwiek sposób inny niż działanie czysto fizyczne lub mechaniczne.

Za produkt biobójczy uznaje się poddany działaniu produktów biobójczych wyrób o podstawowej funkcji biobójczej”.

Powyższa definicja obejmuje, po pierwsze - produkty dotychczas uznawane za biobójcze (biocydy w ujęciu sensu stricto). Po drugie, rozszerzono tę grupę o środki biobójcze wytwarzane in situ, a więc takie, które są otrzymywane w trakcie stosowania z innych substancji (prekursorów). Po trzecie, za produkty biobójcze formalnie są uznawane także wyroby poddane działaniu produktów biobójczych sensu stricto (tzw. treated articles), jeśli ich podstawowa funkcja ma charakter biobójczy, co będzie wiązało się zgodnie z art. 58 BPR z wymogiem właściwego oznakowania.

W ramach analizy pojęcia produktu biobójczego można wyróżnić trzy przesłanki łącznie warunkujące kwalifikację danego środka jako biobójczego, a oparte na:

a) kryterium substancji czynnej wchodzącej w skład produktu;

b) kryterium postaci produktu dostarczanej użytkownikowi;

c) kryterium przeznaczenia produktu i sposobu jego działania (funkcjonalne) ${ }^{23}$.

Warto wskazać, że substancją czynną biocydu jest zawsze substancja działająca na organizmy szkodliwe lub przeciwko nim, ewentualnie mikroorganizm mający takie działanie ${ }^{24}$. Co istotne, substancją czynną stanowiącą produkt biobójczy (albo wchodzącą w skład mieszaniny tworzącej produkt biobójczy) nie może być dowolna substancja chemiczna, a jedynie taka, która została objęta programem przeglądu w celu zatwierdzenia do stosowania $\mathrm{w}$ produktach biobójczych. Należą do nich substancje wymienione w załączniku II rozporządzenia Komisji nr 1451/2007 z dnia 4 grudnia 2007 r. w sprawie drugiej

23 M. Wilbrandt-Gotowicz, Produkty biobójcze - prawne aspekty wprowadzania do obrotu, Toruń 2013, s. 41.

24 Por. art. 3 ust. 1 lit. c) BPR. 
fazy 10-letniego programu pracy określonego w art. 16 ust. 2 dyrektywy 98/8/WE Parlamentu Europejskiego i Rady dotyczącej wprowadzania do obrotu produktów biobójczych ${ }^{25}$ jako tzw. istniejące substancje czynne, a więc takie, które znajdowały się na rynku 14 maja 2000 r. jako podstawowy składnik produktu biobójczego nieprzeznaczonego wyłącznie do celów badawczych lub rozwojowych ${ }^{26}$. Po zakończeniu okresu przejściowego (tj. obecnie po 31 grudnia 2024 r.) dopuszczone do obrotu będą natomiast mogły być jedynie produkty zawierające substancje czynne ocenione pozytywnie, a zatem zatwierdzone na podstawie rozporządzenia $\mathrm{nr} 528 / 2012$ (w tym uprzednio włączone do załącznika I lub I A dyrektywy 98/8/WE) i wpisane do odpowiedniego wykazu ${ }^{27}$.

$\mathrm{W}$ ramach BPR kontynuuje się zatem program prac zapoczątkowany dyrektywą 98/8/WE ${ }^{28}$. Zatwierdzając daną substancję, Komisja wydaje rozporządzenie wykonawcze (określające warunki zatwierdzenia), a w przypadku braku realizacji wymagań - decyzję wykonawczą o niezatwierdzeniu danej substancji (art. 9 ust. 1 BPR). Odnotować należy ustanowienie w art. 4-16 BPR szczegółowych reguł proceduralnych związanych z unijnymi postępowaniami dotyczącymi zatwierdzania substancji czynnych (ich odnawiania i przeglądu), stanowiących istotne uzupełnienie rozporządzenia nr 1451/2007.

W odniesieniu do postaci produktu dostarczanej użytkownikowi wskazać należy, że w zasadzie biocyd nie stanowi półproduktu, lecz gotowy produkt przeznaczony do realizacji celów związanych z kontrolowaniem organizmów szkodliwych.

25 Dz.Urz. UE L 325 z 11.12.2007, s. 3 ze zm.

26 Nie wyklucza to jednak możliwości oceny i zatwierdzenia substancji czynnej, która nie występowała wówczas na rynku (tzw. nowej substancji czynnej). Por. M. Wilbrandt-Gotowicz, op.cit., s. 45.

27 Substancje czynne włączone do załącznika I dyrektywy 98/8/WE uznaje się z mocy prawa jako zatwierdzone na podstawie BPR, umieszczając w wykazie udostępnianym i aktualizowanym przez Komisję. Por. art. 9 ust. $2 \mathrm{w}$ związku z art. 86 BPR. Substancje włączone do załącznika IA dyrektywy są zaś kwalifikowane na mocy rozporządzenia jako substancje wskazane w załączniku I BPR objęte uproszczoną procedurą udzielania pozwoleń. Por. art. 25-28 BPR.

28 Por. art. 89 ust. 1 BPR. 
Odmienna sytuacja dotyczy w świetle art. 3 ust. 1 lit. a) BPR jedynie wąskiej kategorii produktów wytwarzanych in situ.

W kontekście przesłanki funkcjonalnej warto natomiast zaznaczyć, że zamierzone przeznaczenie produktu (rozumiane jako wywoływany efekt biobójczy) zostało w art. 3 ust. 1 lit. a) BPR określone, podobnie jak w dyrektywie 98/8/WE, szeroko jako: „niszczenie, odstraszanie, unieszkodliwianie organizmów szkodliwych, zapobieganie ich działaniu lub zwalczanie", posłużono się jednak inną terminologią w zakresie sposobu działania produktu $^{29}$. O ile bowiem w dotychczasowych aktach prawnych mowa jest o działaniu chemicznym lub biologicznym, w tekście BPR pojawia się: „jakikolwiek sposób inny niż działanie czysto fizyczne lub mechaniczne". Zamiast określenia pozytywnego, użyto zatem negacji, co ma na celu usunięcie ewentualnych wątpliwości kwalifikacyjnych ${ }^{30}$.

Definicja legalna produktów biobójczych obejmuje w związku z powyższym substancje i mieszaniny o różnych zastosowaniach. Ich podział na kategorie (według ogólnego przeznaczenia) oraz grupy (według szczegółowego przeznaczenia) był dotychczas określony w (transponującym załącznik $\mathrm{V}$ dyrektywy 98/8/WE) rozporządzeniu Ministra Zdrowia z dnia 17 stycznia 2003 r. $^{31}$ Od 1 września 2013 r. za zasadne należy natomiast uznać stosowanie podziału wprowadzonego załącznikiem $\mathrm{V}$ do BPR.

W rozporządzeniu nr 528/2012 nie wyróżniono mającej marginalne dotychczas znaczenie kategorii produktów biobójczych niskiego ryzyka ${ }^{32}$, dla których udostępniania na rynku nie było wymagane pozwolenie na wprowadzanie do obrotu, lecz decyzja o wpisie do rejestru produktów biobójczych niskiego ry-

29 Por. M. Wilbrandt-Gotowicz, op.cit., s. 54.

30 Por. wyrok ETS z dnia 1 marca 2012 r. w sprawie C-420/10 Söll GmbH v. Tetra GmbH, niepubl., w którym opowiedziano się za tym, że działanie chemiczne lub biologiczne produktu biobójczego może mieć charakter bezpośredni, jak również pośredni, jeżeli produkt jest przeznaczony do wywołania skutku hamującego względem organizmów szkodliwych.

31 Rozporządzenie Ministra Zdrowia w sprawie kategorii i grup produktów biobójczych według ich przeznaczenia, Dz.U. z 2003 r. Nr 16, poz. 150.

32 Por. art. 3 pkt 2 u.p.b. i art. 2 ust. 1 lit. b) BPD. 
zyka (stanowiącego część II Rejestru Produktów Biobójczych, o którym mowa w art. 22 i 23 u.p.b.), wydawana wszakże jedynie w nieco krótszym terminie niż pozwolenie ${ }^{33}$. Tryb ten zastąpiono uproszczoną procedurą udzielania pozwoleń względem tzw. produktów o korzystniejszym profilu dla środowiska lub zdrowia ludzi lub zwierząt ${ }^{34}$, które spełniają warunki określone w art. 25 BPR. Warto zasygnalizować możliwość poszerzenia wykazu substancji objętych procedurą uproszczoną (zawartego w załączniku I BPR), co może mieć wpływ na ewentualne jej rozpowszechnienie ${ }^{35}$.

Nową kategorią z rozporządzenia nr 528/2012 jest tzw. rodzina produktów biobójczych, rozumiana zgodnie z art. 3 ust. 1 lit. s) BPR jako grupa produktów biobójczych o podobnych zastosowaniach, zawierających takie same substancje czynne, o podobnym składzie z określonymi różnicami oraz o podobnym poziomie ryzyka i skuteczności. Produkty należące do jednej rodziny powinny zatem charakteryzować się zbliżonym składem i właściwościami, co uzasadnia przyjęcie uproszczonych form ich dopuszczania do obrotu - jednego pozwolenia obejmującego nie konkretny produkt, lecz całą ich rodzinę. Wprowadzanie do obrotu nowego produktu z danej rodziny objętej pozwoleniem ma w założeniach wymagać jedynie uprzedniego poinformowania o takim zamiarze właściwego organu państwa członkowskiego - w odniesieniu do pozwoleń krajowych albo Komisji Europejskiej i ECHA - w przypadku pozwoleń unijnych (art. 17 ust. 6 BPR). Pozytywnie ocenia się na tym tle również ułatwienia w zakresie rejestracji takich samych produktów (art. 17 ust. 7 BPR oraz rozporządzenie Komisji nr 414/2013), jak rów-

33 Por. np. art. 10 ust. 2 u.p.b.

34 Pojęciem powyższym posłużono się jednak jedynie w motywie 29 BPR, nie definiując go w tekście rozporządzenia, a jedynie wskazując względem jakich produktów może być wydane unijne pozwolenie w trybie uproszczonym.

35 Por. art. 28 ust. 1 i 3 BPR oraz rozporządzenie Komisji nr 88/2014 z dnia 31 stycznia 2014 r. określające procedurę zmiany załącznika I do rozporządzenia Parlamentu Europejskiego i Rady (UE) nr 528/2012 w sprawie udostępniania na rynku i stosowania produktów biobójczych, Dz.Urz. UE L 32 z 1.02.2014, s. 3. 
nież wprowadzenie możliwości odstępstw od wymogu dostarczenia określonych danych ad casum (art. 21 BPR).

\section{TRYBY UDZIELANIA I ZMIANY POZWOLEŃ NA PRODUKTY BIOBÓJCZE}

W rozporządzeniu nr 528/2012 utrzymano wymóg uzyskania indywidualnego pozwolenia na wprowadzanie do obrotu produktu biobójczego (ewentualnie rodziny takich produktów $)^{36}$. W art. 17 ust. 1 BPR wprost stwierdzono, że: „produktów biobójczych nie można udostępniać na rynku ani stosować, jeśli nie uzyskały pozwolenia zgodnie z niniejszym rozporządzeniem". Jednocześnie przewidziano szereg środków intertemporalnych dotyczących zachowania ważności pozwoleń wydanych zgodnie z przepisami krajowymi implementującymi dyrektywę 98/8/WE oraz stosowania w okresie przejściowym tzw. procedur narodowych, czyli krajowych przepisów niezharmonizowanych względem produktów zawierających substancje czynne, których przegląd nie został jeszcze zakończony (ewentualnie maksymalnie do trzech lat od momentu ich zatwierdzenia, lecz nie później niż do 31 grudnia 2024 r.) ${ }^{37}$. W prawie polskim reguły te były dotychczas unormowane w art. 54 u.p.b. (jako tzw. pozwolenia na obrót w okresie przejściowym), charakteryzując się oceną właściwości produktu sprowadzoną przede wszystkim do jego potwierdzonej skuteczności. W drodze odstępstwa od powyższego, dla produktów zawierających nowe substancje czynne (tzn. nie występujące na rynku w dniu 14 maja 2000 r.), które nie zostały jeszcze ocenione i zatwierdzone, możliwe jest natomiast wydanie przez właściwy organ krajowy lub Komisję Europejską pozwolenia tymczasowego na okres do trzech lat (art. 55 ust. 2 BPR).

36 Wymóg uzyskania pozwolenia nie dotyczy wyrobów poddanych działaniu produktów biobójczych, które powinny być oznakowane zgodnie z art. 58 BPR.

37 Por. art. 89 ust. 2 BPR. 
W odniesieniu to produktów zawierających zatwierdzone substancje czynne zawsze mają natomiast bezpośrednie zastosowanie przepisy BPR przewidujące dwa główne tryby uzyskiwania pozwoleń:

- pozwolenia krajowe w odniesieniu do produktów zawierających zatwierdzone $\mathrm{w}$ unijnym programie przeglądu substancje czynne (w pełni zunifikowane z BPR - tzw. rejestracja wg norm europejskich) oraz

- pozwolenia wydawane przez Komisję Europejską (tzw. pozwolenia unijne) ${ }^{38}$.

BPR zawiera w odniesieniu do wskazanych wyżej trybów szczegółową regulację proceduralną. Z tego powodu jest jednym z pierwszych unijnych aktów bezpośrednio skutecznych w porządkach prawnych państw członkowskich, które w sposób kompleksowy normuje kwestie procesowe związane $\mathrm{z}$ wszczęciem, przebiegiem i rozstrzygnięciem postępowania administracyjnego prowadzonego także przez właściwy organ krajowy. Podkreślić należy, że dotyczy to również stanów faktycznych niezwiązanych z istnieniem elementu transgranicznego. Organ krajowy na wniosek przedsiębiorcy przeprowadza bowiem postępowanie $\mathrm{w}$ sprawie wydania pozwolenia dopuszczającego produkt biobójczy do obrotu jedynie na terytorium tego państwa, będąc związany w pierwszym rzędzie nie tylko unijnymi przepisami materialnoprawnymi, lecz także regułami proceduralnymi. Dotyczą one przykładowo wstępnej oceny wniosku wszczynającego postępowanie, jego ewentualnego „zatwierdzenia” bądź „odrzucenia”39. W rozporządzeniu nr 528/2012 posłużono się terminologią odnoszącą się w wielu wypadkach do instytucji $\mathrm{w}$ takim kształcie niewystępujących w krajowych przepisach proceduralnych (przede wszystkim w kodeksie postępowania administracyjnego ${ }^{40}$ ). Podkreślić należy zatem wagę przyjęcia wewnętrznych przepisów, które pozwalałyby na zapewnienie faktycznego wdrożenia przepisów BPR w praktyce

38 Por. art. 17 i n. BPR.

39 Por. art. 29 BPR.

40 Ustawa z dnia 14 czerwca 1960 r. - Kodeks postępowania administracyjnego, tj. Dz.U. z 2013 r., poz. 267 ze zm. 
organu krajowego (Prezesa Urzędu Rejestracji Produktów Leczniczych, Wyrobów Medycznych i Produktów Biobójczych), jak również kompatybilność z aktami unijnymi, jak i ugruntowanymi w prawie polskim instytucjami administracyjnego prawa procesowego.

Wydawane przez Komisję Europejską pozwolenia unijne obejmują (w odróżnieniu od pozwoleń krajowych) co do zasady terytorium całej UE. Co istotne, w każdym państwie członkowskim nadają one te same prawa i nakładają te same obowiązki, jakie wynikają z pozwolenia krajowego bez konieczności uzyskiwania zezwoleń w każdym z krajów osobno lub przeprowadzenia postępowania w sprawie wzajemnego uznania (art. 41 BPR). Powyższa procedura będzie dostępna dla produktów, które mają podobne warunki stosowania w całej Unii, w pierwszej kolejności dla produktów zawierających nowe substancje czynne oraz produktów kwalifikujących się do postępowania uproszczonego na podstawie art. 25 BPR. Rozszerzanie zakresu postępowania na kolejne grupy produktowe będzie następowało zgodnie $\mathrm{z}$ harmonogramem określonym $\mathrm{w}$ art. $42 \mathrm{BPR}^{41}$. Pozwolenia unijne przyjmują formę rozporządzeń wykonawczych Komisji, odmowa ich udzielenia następuje w drodze decyzji wykonawczej ${ }^{42}$. Wskazać należy, że przepisy BPR szczegółowo określają warunki wszczęcia oraz przebieg postępowania $\mathrm{w}$ omawianym przedmiocie, w którym istotną rolę odgrywają zarówno właściwe organy państw członkowskich, jak i Europejska Agencja Chemikaliów, odpowiedzialne za opiniowanie realizacji prawnych wymagań uzyskania pozwolenia.

W celu rozszerzenia rynku zbytu dla produktu zarejestrowanego już w co najmniej jednym z państw członkowskich możliwe jest natomiast przeprowadzenie procedury wzajemnego uznawania pozwoleń (tzw. mutual recognition procedure MRP). Była ona uregulowana także w czasie obowiązywania dyrektywy 98/8/WE, jednak brak bezpośredniej skuteczności przepisów utrudniał ich stosowanie w praktyce. W rozporządzeniu nr 528/2012 położono nacisk na urealnienie tej insty-

41 M. Wilbrandt-Gotowicz, op.cit., s. 107.

42 Por. art. 44 ust. 5 BPR. 
tucji, wyczerpująco odnosząc się nie tylko do wspomnianej procedury tzw. uznawania sekwencyjnego (w którym inne państwo/a uznają pozwolenie wydane uprzednio przez organ jednego z państw członkowskich), ale również wprowadzając tryb tzw. równoległego uznawania pozwoleń. Jest on obecnie dostępny dla produktów, które nie uzyskały wcześniej zharmonizowanego pozwolenia w żadnym $\mathrm{z}$ państw członkowskich. Co istotne, przyjęto tu sieciowy schemat powiązanych ze sobą zunifikowanych postępowań krajowych z elementem transnarodowym. Jedno z państw uzyskuje bowiem w konkretnej sprawie status państwa wiodącego, referencyjnego (tzw. reference Member State - RMS), a jego właściwy organ - organu referencyjnego dokonującego oceny produktu. Z postępowaniem w sprawie wydania pozwolenia $\mathrm{w}$ tym państwie jest jednak bezpośrednio skorelowane postępowanie/a w sprawie uznania pozwolenia w jednym lub większej liczbie pozostałych państw, tzw. państw zainteresowanych (Member States concerned - CMS) ${ }^{43}$.

Od wzajemnego uznawania sekwencyjnego lub równoległego należy natomiast odróżnić postępowanie, którego celem jest wydanie zgody na tzw. handel równoległy. Rozporządzenie nr 528/2012 jest pierwszym aktem prawnym regulującym obrót biocydami, ustanawiającym $\mathrm{w}$ art. 53 zharmonizowane reguły dotyczące handlu równoległego identycznymi produktami, na które wydano pozwolenia w różnych państwach członkowskich. Jego istota polega na możliwości wprowadzenia do obrotu produktu, który uzyskał pozwolenie w danym kraju (państwie pochodzenia) - w innym państwie członkowskim (państwie wprowadzenia), jeżeli w państwie wprowadzenia dopuszczono do

43 Por. art. 34 BPR. Pełne postępowanie wyjaśniające odbywa się w takim układzie w państwie referencyjnym, odpowiedzialnym za sporządzenie projektu sprawozdania z oceny i aktualnej charakterystyki produktu biobójczego. Pozostałe państwa zainteresowane na tej podstawie mogą zaakceptować ich treść i wydać w uproszczonej względem zwykłego postępowania krajowego procedurze własne pozwolenia dopuszczające biocyd do obrotu. Na uwagę zasługują również oparte na praktykach ADR regulacje w zakresie rozwiązywania problemów odstępstw i sprzeciwów od wzajemnego uznawania pozwoleń (art. 35-37 BPR). 
obrotu produkt referencyjny ${ }^{44}$. Po pierwsze, wskazać należy, iż prawodawca opowiedział się za warunkiem, by produkt objęty zezwoleniem na handel równoległy był „taki sam jak produkt referencyjny"45, co wymaga wykazania we wniosku o wydanie zgody na handel równoległy. Po drugie, zgodnie z art. 53 ust. 3 BPR, produkt biobójczy uznaje się za taki sam jak produkt referencyjny jedynie w przypadku, gdy spełnione są ścisłe reguły referencyjności ${ }^{46}$, które w praktyce istotnie ograniczają możliwości stosowania tej instytucji.

Wszystkie typy pozwoleń udzielanych na podstawie BPR udzielane są na określony czas nieprzekraczający 10 lat $^{47}$, licząc od daty pierwszego albo kolejnego zatwierdzenia substancji czynnej i nieprzekraczający terminu ważności określonego dla danej substancji czynnej wraz z wpisem do wykazu. Z tego względu, za zasadne uznano uregulowanie procedury odnawiania pozwoleń w odniesieniu do produktów zawierających substancje czynne, których okres zatwierdzenia również został przedłużony ${ }^{48}$.

Szczególnie interesująco jawią się jednak rozwiązania prawne przyjęte w odniesieniu do zmiany warunków udzielanych pozwoleń, przede wszystkim z inicjatywy posiadacza pozwolenia. W rozporządzeniu nr 528/2012 wyróżniono bowiem trzy rodzaje dokonywanych w pozwoleniu zmian: „zmianę ad-

44 Por. M. Wilbrandt-Gotowicz, op.cit., s. 275.

45 Por. art. 53 ust. 1 i 2 BPR.

46 M.in. w zakresie specyfikacji, zawartości substancji czynnej, opakowania oraz wytworzenia przez to samo przedsiębiorstwo, przez przedsiębiorstwo powiązane lub na licencji $\mathrm{w}$ takim samym procesie produkcyjnym.

47 Por. art. 17 ust. 4 BPR. W przypadku pozwoleń wydawanych po przeprowadzeniu oceny porównawczej - na 5 lat - por. art. 23 ust. 6 BPR. Zezwolenie na handel równoległy ma taki sam okres ważności, jak pozwolenie na produkt referencyjny w państwie członkowskim wprowadzenia - por. art. 53 ust. $6 \mathrm{BPR}$. Pozwolenie tymczasowe dla produktów zawierających nowe substancje czynne może być wydane na okres nieprzekraczający 3 lat - por. art. 55 ust. 2 BPR.

48 Por. art. 31 BPR w odniesieniu do pozwoleń krajowych, art. 45 i 46 BPR w odniesieniu do pozwoleń unijnych, art. 53 ust. 7 w zakresie zgód na handel równoległy, rozporządzenie delegowane Komisji (UE) nr 492/2014 dotyczące odnawiania pozwoleń w procedurze wzajemnego uznawania. 
ministracyjną"49, „drobną zmianę"50 oraz „istotną zmianę"51. W zależności od jej rodzaju odpowiednio stosowana powinna być uproszczona procedura powiadamiania, skrócony okres oceny albo okres oceny proporcjonalny do zakresu proponowanej zmiany (art. 51 BPR). Szczegółowe kwestie związane z niniejszą procedurą uregulowano w rozporządzeniu Komisji (UE) nr 354/2013 z dnia 18 kwietnia 2013 r. ${ }^{52}$ Ze względu na odmienny charakter poszczególnych elementów zawartych w pozwoleniu powyższe rozwiązania należy ocenić pozytywnie.

Na zakończenie tej części warto podkreślić znaczenie unijnego Rejestru Produktów Biobójczych (R4BP) jako narzędzia komunikacyjnego i informacyjnego w procedurach rejestracyjnych. Po 1 września 2013 r. wnioskodawcy w sprawach udzielenia, odnowienia bądź zmiany pozwolenia na produkt biobójczy w ramach trybów przewidzianych w BPR obligatoryjnie powinni korzystać z tego systemu. Także właściwe organy i Komisja Europejska odnotowują w nim na bieżąco wszystkie decyzje podjęte w sprawie zunifikowanych pozwoleń, w tym dane dotyczące ewentualnej zmiany pozwolenia, jego unieważnienia czy odnowienia ${ }^{53}$.

49 Zgodnie z art. 3 ust. 1 pkt aa) BPR oznacza ona: „zmianę w istniejącym pozwoleniu, która ma charakter czysto administracyjny i nie wiąże się ze zmianą właściwości ani skuteczności produktu biobójczego lub rodziny produktów biobójczych".

50 Zgodnie z art. 3 ust. 1 pkt ab) BPR oznacza ona: „zmianę w istniejącym pozwoleniu, która nie ma charakteru czysto administracyjnego, ale wymaga ponownej oceny właściwości lub skuteczności produktu biobójczego lub rodziny produktów biobójczych tylko w niewielkim zakresie".

51 Zgodnie z art. 3 ust. 1 pkt ac) BPR oznacza ona: „zmianę w istniejącym pozwoleniu, która nie jest ani zmianą administracyjną, ani drobną zmianą”.

52 Rozporządzenie w sprawie zmian produktów biobójczych, na które udzielono pozwolenia zgodnie z rozporządzeniem Parlamentu Europejskiego i Rady (UE) nr 528/2012, Dz.Urz. UE L 109 z 19.04.2013 r., s. 4.

53 Komisja może przyjąć akty wykonawcze w celu uszczegółowienia informacji przekazywanych za pośrednictwem rejestru, jak również sposobów wymiany informacji w przypadku niefunkcjonowania w pełni R4BP do 1 września 2013 r. lub jego późniejszej awarii. Por. art. 71 ust. 6-9 BPR. 


\section{OCHRONA DANYCH O SUBSTANCJACH CZYNNYCH I PRODUKTACH BIOBÓJCZYCH}

Wytworzenie dokumentacji wymaganej $\mathrm{w}$ procesie zatwierdzania substancji czynnych, a następnie rejestracji produktów biobójczych, wiąże się z poniesieniem określonych kosztów. Unijny przegląd substancji opiera się bowiem na wyczerpującej analizie właściwości fizyko-chemicznych i metod analitycznych, skuteczności, właściwości toksykologicznych oraz oceny ryzyka dla człowieka, a także właściwości ekotoksykologicznych oraz losów i zachowania w środowisku. W związku z powyższym, w rozporządzeniu nr 528/2012 zawarto rozbudowaną regulację w zakresie ochrony tego typu danych, mających niewątpliwie znaczną wartość handlową. Przyjęte przepisy stanowią próbę wyważenia interesów podmiotów finansujących badania właściwości substancji czynnych i produktów je zawierających z interesami innych przedsiębiorców, którzy także chcieliby uzyskać pozwolenia umożliwiające udostępnianie biocydów na rynku, jak również z wymaganiami ochrony zwierząt i środowiska naturalnego ${ }^{54}$.

W art. 59 ust. 1 rozporządzenia nr 528/2012 expressis verbis wskazano, że dane przekazane (do celów BPD lub BPR) właściwym organom krajowym bądź ECHA nie mogą być wykorzystywane przez te podmioty na korzyść kolejnych wnioskodawców. Od tej zasady wprowadzono dwa główne wyjątki w postaci: posiadania przez kolejnego wnioskodawcę upoważnienia do korzystania $\mathrm{z}$ danych (tzw. letter of access) albo sytuacji, w której upłynął odpowiedni okres ich ochrony. Wspomniane upoważnienie do korzystania $\mathrm{z}$ danych (w świetle art. 61 ust. 1 BPR) powinno zawierać, poza danymi kontaktowymi właściciela danych i beneficjenta, nazwę substancji czynnej lub produktu biobójczego, którego dotyczy, datę, od której upoważnienie staje się skuteczne oraz wykaz przedstawionych danych, do których przytaczania daje ono prawo. Takie upoważnienie nie będzie wymagane po upływie odpowiedniego okresu ochro-

54 M. Wilbrandt-Gotowicz, op.cit., s. 228. 
ny danych (co do zasady 10-letniego ${ }^{55}$ ). W odniesieniu natomiast do substancji, co do których przed 1 września 2013 r. nie podjęto decyzji o włączeniu do załącznika I dyrektywy 98/8/WE (w określonej grupie produktowej), termin ochrony danych ma się zakończyć zgodnie z art. 95 ust. 5 BPR w jednolitym terminie - 31 grudnia $2025 \mathrm{r}$.

Istotne znaczenie praktyczne ma również fakt prowadzenia przez ECHA publicznie dostępnego wykazu substancji czynnych i ich producentów i dostawców, dla których przedłożono wymaganą prawem dokumentację w celu zatwierdzenia danej substancji. Interesy przedsiębiorców, którzy ponieśli koszty jej wytworzenia, mają być chronione $\mathrm{w}$ ten sposób, że od dnia 1 września 2015 r. zaktualizuje się zakaz wprowadzania do obrotu produktów biobójczych składających się z właściwej substancji zawartej w tym wykazie, zawierających lub wytwarzających tę substancję, chyba że dostawca substancji lub dostawca produktu znajduje się $\mathrm{w}$ wykazie w odniesieniu do grup produktowych, do których należy dany produkt ${ }^{56}$. Tym samym źródła pochodzenia substancji czynnych produktów biobójczych zostaną ograniczone tylko do tych producentów lub importerów, którzy uczestniczyli w procedurze przeglądu substancji czynnej skutkującej jej zatwierdzeniem.

\section{PODSUMOWANIE}

Obszerność i kazuistyczność unijnej regulacji wprowadzania do obrotu produktów biobójczych sprawia, że w niniejszym opracowaniu z konieczności odniesiono się jedynie do najważniejszych modyfikacji stanu prawnego wynikających z wdrażania rozporządzenia nr 528/2012. Jako akt bezpośrednio skuteczny w krajowych porządkach prawnych z pewnością posiada on większą skuteczność regulacyjną niż dyrektywa 98/8/WE. Podkreślić jednak należy, że faktyczny zakres stosowania tego

55 Por. art. 60 ust. 2 i 3 BPR.

56 Por. art. 95 ust. 2 BPR. 
aktu uzależniony jest od tempa przeglądu i zatwierdzania substancji czynnych dla produktów biobójczych, którego zakończenie było kilkukrotnie odkładane, a obecnie przewidziane jest na dzień 31 grudnia 2024 r. Mimo uregulowania kwestii związanych z tą procedurą, nie należy oczekiwać jej zbytniego przyspieszenia w odniesieniu do konkretnych substancji. W związku powyższym, system reglamentacji wprowadzania do obrotu produktów biobójczych wciąż winien być traktowany jako pozostający w fazie kształtowania się, co objawia się m.in. stosowaniem mozaiki procedur ujednoliconych w BPR z krajowymi niezharmonizowanymi rozwiązaniami prawnymi dotyczącymi produktów zawierających niezatwierdzone dotychczas substancje czynne. W prawie polskim nakłada się na nie również dostosowana do treści dyrektywy 98/8/WE, ale już nie do BPR, ustawa o produktach biobójczych z 2002 r. Taki stan rzeczy nie sprzyja z pewnością spójności i przejrzystości systemu prawa.

$\mathrm{Z}$ punktu widzenia doktryny prawa administracyjnego warto zwrócić uwagę na nowatorskość rozporządzenia nr 528/2012 jako jednego z pierwszych unijnych aktów ustanawiających bezpośrednio skuteczne regulacje o charakterze procesowym, mające zastosowanie nie tylko do postępowań prowadzonych przez instytucje unijne przy współudziale organów krajowych czy procedur wzajemnego uznawania pozwoleń o charakterze transgranicznym, ale także przez organy krajowe w celu wydania pozwolenia obejmującego terytorialnie jedynie dane państwo członkowskie. W tym kontekście mówić można o pewnym zespole zintegrowanych procedur administracyjnych ujednoliconych w ramach państw członkowskich w następstwie mechanizmu bezpośredniej harmonizacji.

Z perspektywy rynku produktów biobójczych BPR winno być postrzegane jako stanowiące nieco zmodyfikowaną, uszczegółowioną wersję rozwiązań prawnych zapoczątkowanych dyrektywą 98/8/WE, co jednak samo w sobie nie może stanowić o pełnej akceptacji dla przyjętych rozwiązań. Wątpliwości wiążą się ze stopniem zawiłości redakcyjnej przepisów i mnogością wewnętrznych odesłań, co prowadzić może do niezamierzonych luk i wątpliwości interpretacyjnych. Część z nich usunięto rozporządzeniem nr 334/2014, spodziewać można się jednak 
kolejnych modyfikacji tekstu BPR jeszcze przed zakończeniem okresu przejściowego. Duże nadzieje wiąże się z trybem udzielania pozwoleń dla rodziny produktów biobójczych czy uproszczoną procedurą oceny produktów spełniających wymagania określone w art. 25 BPR. Pozytywnie należy z pewnością ocenić wprowadzenie gradacji możliwych zmian w pozwoleniach na produkty biobójcze i dostosowaniem $\mathrm{w}$ tym kontekście trybu postępowania (w tym tzw. milczącej zgody organu) oraz zakresu postępowania wyjaśniającego. Istotną barierą w dostępie do rynku będą natomiast z pewnością koszty postępowań rejestracyjnych, czas trwania (standardowo 365 dni), jak i ograniczenia związane z ochroną danych i zakazem wprowadzania od 1 września 2015 r. do obrotu produktów zawierających substancje niepochodzące od podmiotów wpisanych do właściwego wykazu ECHA.

Wydaje się, że obecnie nie ma już odwrotu od stosowania w ramach UE jednolitych materialnych, a w dużym zakresie także procesowych, reguł uzyskiwania pozwoleń dotyczących produktów biobójczych. System ten ma zapewnić wysoki standard dbałości o środowisko naturalne oraz bezpieczeństwo dla zdrowia i życia ludzkiego. Prowadzi to jednak do stworzenia rynku o wysokich barierach dostępu dla przedsiębiorców, co może przyczyniać się do ograniczenia innowacyjności i konkurencyjności produktów.

\section{BIBLIOGRAFIA}

Wilbrandt-Gotowicz M., Produkty biobójcze - prawne aspekty wprowadzania do obrotu, Torun 2013.

Kontakt - e-mail:

m.gotowicz@uksw.edu.pl 